\title{
Mambangun Prestasi Atlet Tenis Lapangan Melalui Pendekatan Psikologis
}

\author{
Didik Rilastiyo Budi \\ Jurusan Pendidikan Jasmani, FIkes, Universitas Jenderal Soedirman \\ didik.rilastiyo.budi@unsoed.ac.id
}

\begin{abstract}
ABSTRAK
Tenis lapangan merupakan salah satu olahraga yang disebut sebagai "Top of Sport" karena memiliki karakteristik permainan yang cepat, determinasi tinggi dan memerlukan pengambilan keputusan yang tepat dalam waktu singkat. Di indonesia, tenis lapangan pada perkembangannya telah memiliki banyak atlet dari berbagai daerah yang potensial dan dapat bersaing di tingkat nasional maupun internasional. Program latihan telah dijalankan oleh pelatih dan berbagai klub atau sekolah tenis untuk meningkatkan keterampilan dan prestasi atlet. Pada masa pandemi Covid 19, program latihan yang dijalankan harus mengalami perubahan dan inovasi, sehingga atlet-atlet tenis di daerah dapat tetap berlatih. Salah satu program yang perlu dijalankan dan dikembangkan dalam proses latihan pada masa pandemi Covid 19 yaitu program latihan mental atau psikologi. Dengan pendekatan psikologi maka diharapkan para atlet tenis daerah tetap memiliki motivasi yang tinggi dalam berlatih dan berprestasi ditengan pandemi Covid 19 yang belum juga usai.
\end{abstract}

Kata Kunci: Atlet, Pendekatan Psikologis, Prestasi, Tenis Lapangan 
Pandemi Covid 19 yang sedang melanda di seluruh dunia telah memberikan dampak yang sangat besar di berbagai sektor, dimulai dari kesehatan, ekonomi, sosial, pendidikan dan juga dibidang olahraga. Dibidang olahraga, terjadinya pandemi Covid 19 telah merubah banyak hal, diantaranya perubahan jadwal pertandingan, perlombaan dan kejuaraan. Selain itu, perubahan juga terjadi pada perencanaan program latihan dan pembinaan yang dilakukan oleh atlet dan klub/sekolah tenis lapangan.

Perubahan atau bahkan terhentinya program latihan yang telah dijalankan secara rutin dan terprogram dapat mempengaruhi prestasi serta mentalitas atlet. Program latihan merupakan hal yang penting untuk meningkatkan keterampilan bermain tenis (Sahan A et al., 2018; Syafei et al., 2019). Berdasarkan pernyataan tersebut maka pelaksanaan program latihan sangat diperlukan oleh atlet untuk dapat meningkatkan keteampilan teknik dasar dan keterampilan bermain tenis lapangan.

Program latihan yang dijalankan dengan baik juga tidak hanya untuk meningkatkan performa atlet, akan tetapi juga dapat membantu atlet untuk dapat terhindar dari berbagai kemungkinan terjadinya cedera (Syafei et al., 2020). Pada usia remaja, atlet tenis berpotensi mengalami berbagai cedera karena tidak menerapkan program latihan dengan tepat (Budi, Agustan, et al., 2020). Berdasarkan hal tersebut maka program latihan yang tepat perlu diberikan kepada atlet.

Program latihan yang diterapkan oleh pelatih pada olahraga tenis lapangan, tidak hanya berfokus pada aspek fisik dan teknik saja akan tetapi perlu diberikan program latihan pada aspek psikologis pada atlet. Latihan yang dilakukan oleh atlet perlu ditambahkan berbagai program latihan psikologis dan pola konsumsi nutrisi selain program latihan fisik dan teknik (Budi, Syafei, et al., 2020; Kusuma, Syafei, \& Rilastiyo, 2019).

Aspek psikolos menjadi aspek yang sangat penting dalam mendukung pencapaian prestasi pada atlet, akan tetapi pada proses program latihan komponen psikologis sering kali dilupakan oleh sebagian besar pelatih. Pada program latihan moderen, aspek psikologis atlet menjadi salah satu program yang harus ada pada penerapan Sport Science sebagai upaya mewujudkan pencapaian performa dan 
prestasi olahraga di tingkat nasional maupun internasional (Kusuma, Syafei, \& Budi, 2019).

Atlet dengan pengendalian psikologis yang baik memilki potensi untuk mencapai prestasi lebih tinggi yang didukung dengan aspek fisik, teknik dan taktik yang baik (Kamnuron et al., 2020). Aspek psikolog pada atlet tidak dapat diperoleh secara alami, akan tetapi perlu dilatih dalam program latihan dan juga pertandingan secara berkala sehingga akan membentuk mental yang baik pada atlet.

Program latihan pada aspek psikologis pada sasarannya mengarah untuk mengembangkan aspek mental, kepribadian, tanggungjawab, disiplin, pantang menyerah, sportifitas dan sebagainya dengan tujuan untuk menumbuhkembangkan mental juara pada atlet (Effendi, 2016). Pelaksanaan program latihan pada aspek psikolos, pada atlet tenis lapangan dapat dilakukan secara kelompok maupun individu.

Kabuapten Banyumas merupakan salah satu daerah di Provinsi Jawa Tengah yang memiliki potensi yang baik pada cabang olahraga tenis lapangan. Program pembinaan pelatihan telah dikembangkan dari level usia dini, remaja hingga perguruan tinggi (Sayfei et al., 2020). Program pembinaan dilakukan oleh PELTI Kabupaten Banyumas yang berkerjasama dengan berbagai instasi terkait, dengan kerjasama yang baik para atlet tenis Kabupaten Banyumas dapat memperoleh berbagai prestasi di level daerah maupun nasional.
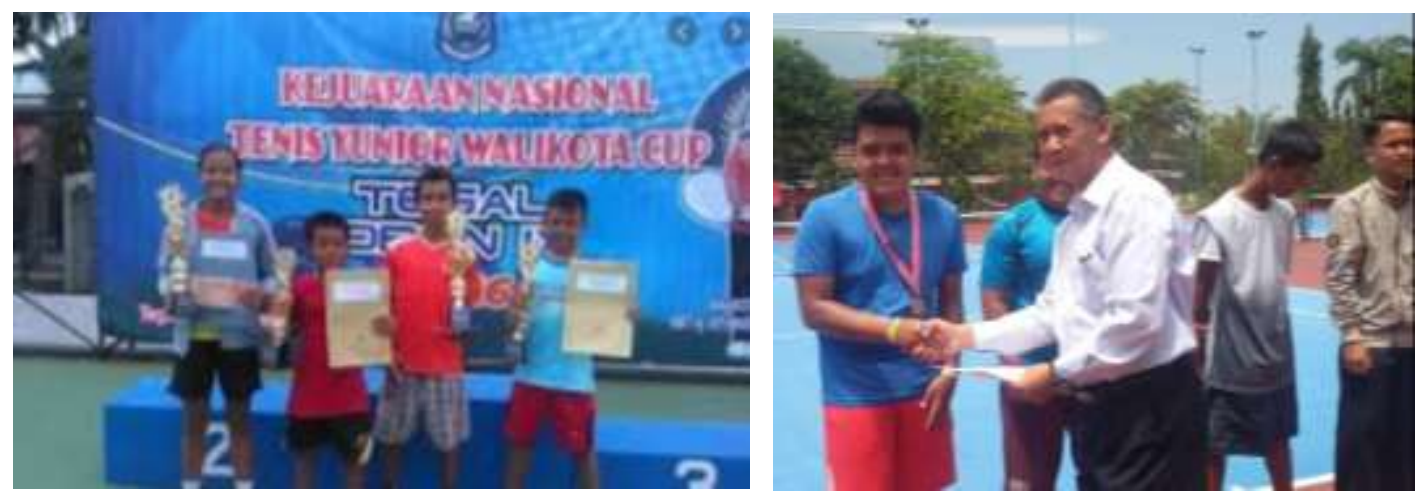

Gambar 1. Prestasi Atlet Junior Kabupaten Banyumas di Kejurnas 


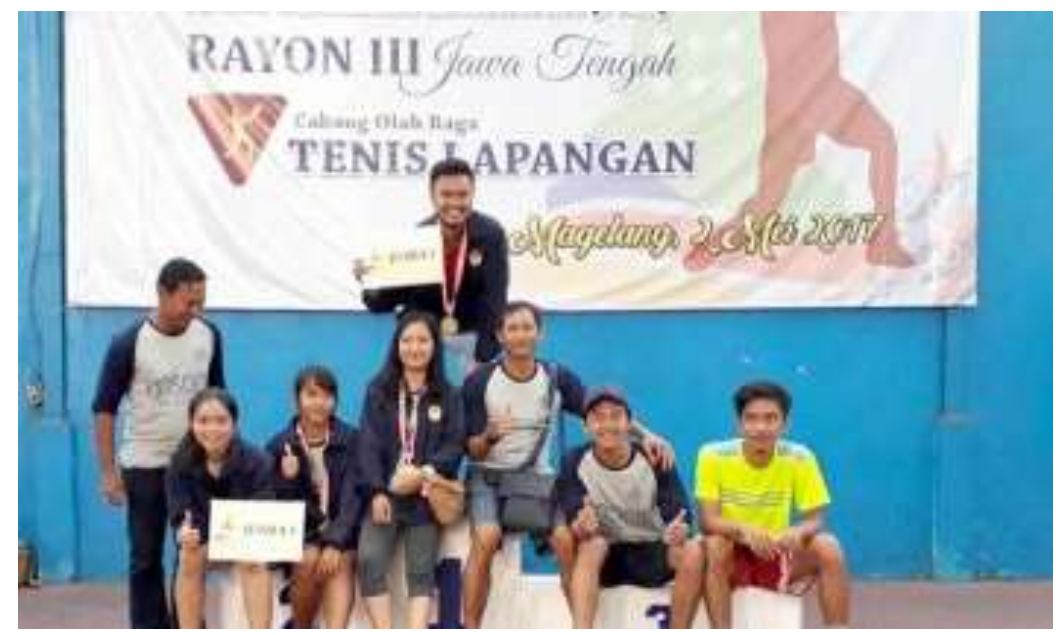

Gambar 2. Prestasi Atlet Tenis Unsoed dan Banyumas di POM Jawa Tengah

Pada masa Pandemi Covid 19, pelaksanaan program latihan atlet tenis lapangan di Kabupaten Banyumas mengalami berbagai kendala yang menyebabkan program tidak berjalan dengan sebagaimana mestinya. Untuk mengembalikan motivasi berlatih pada diri atlet, pelatih dan pengurus PELTI Kabupaten Banyumas melakukan pendekatan psikologis kepada atlet untuk dapat meningkatkan motivasi berlatih.
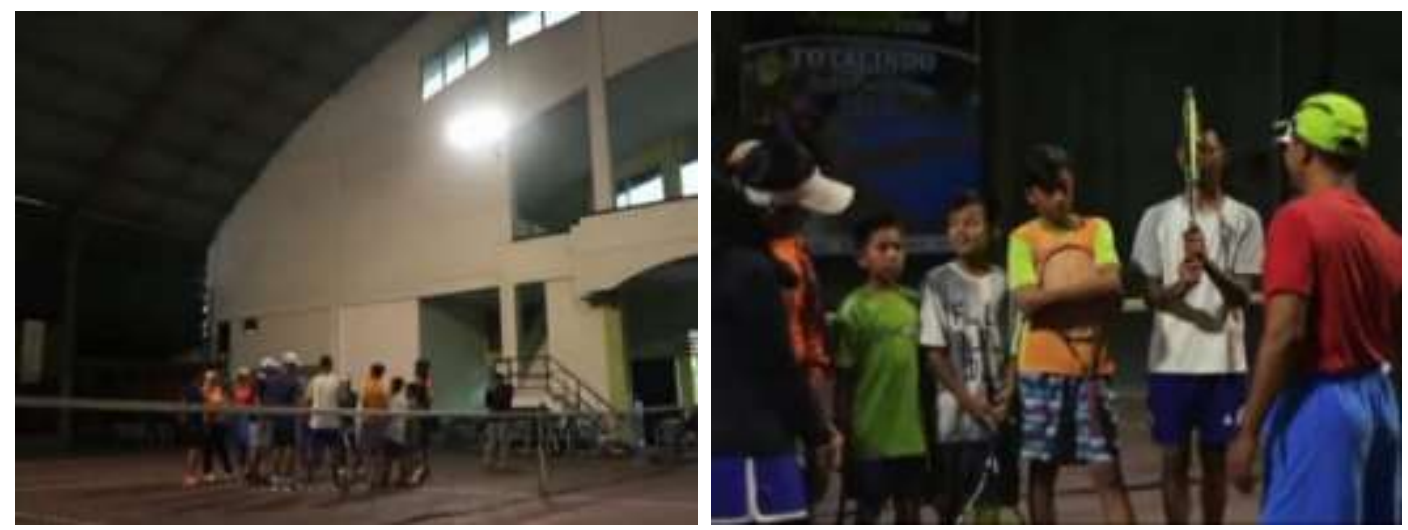

Gambar 3. Pemberian Motivasi Kepada Atlet Pada Saat Latihan 
Program latihan pada aspek psikologis dilakukan dengan berbagai metode diantaranya metode pemberian motivasi oleh pengurus dan pelatih dengan tujuan untuk meningkatkan rasa percaya diri dan kemauan atlet untuk tetap menjalankan program latihan. Selain itu, metode pelatihan psikoilogis juga dilakukan dengan cara pemberian Emagery Training yang dilakukan dengan cara atlet ditugaskan untuk mebayangkan berbagai kondisi latihan, pertandingan dan kondisi yang menyenangkan sehingga atlet tidak merasa jenuh selama proses latihan.

Untuk melatih konsentrasi atlet, pelatih juga memberikan program dan tes konsentrasi dalam bentuk tes Kraeplin atau angka koran. Hal ini bertujuan untuk melatih daya konsentrasi atlet selama latihan maupun pertandingan, sehingga walaupun dalam kondisi kelelahan diharapkan atlet tetap bisa memiliki konsentrasi yang baik.

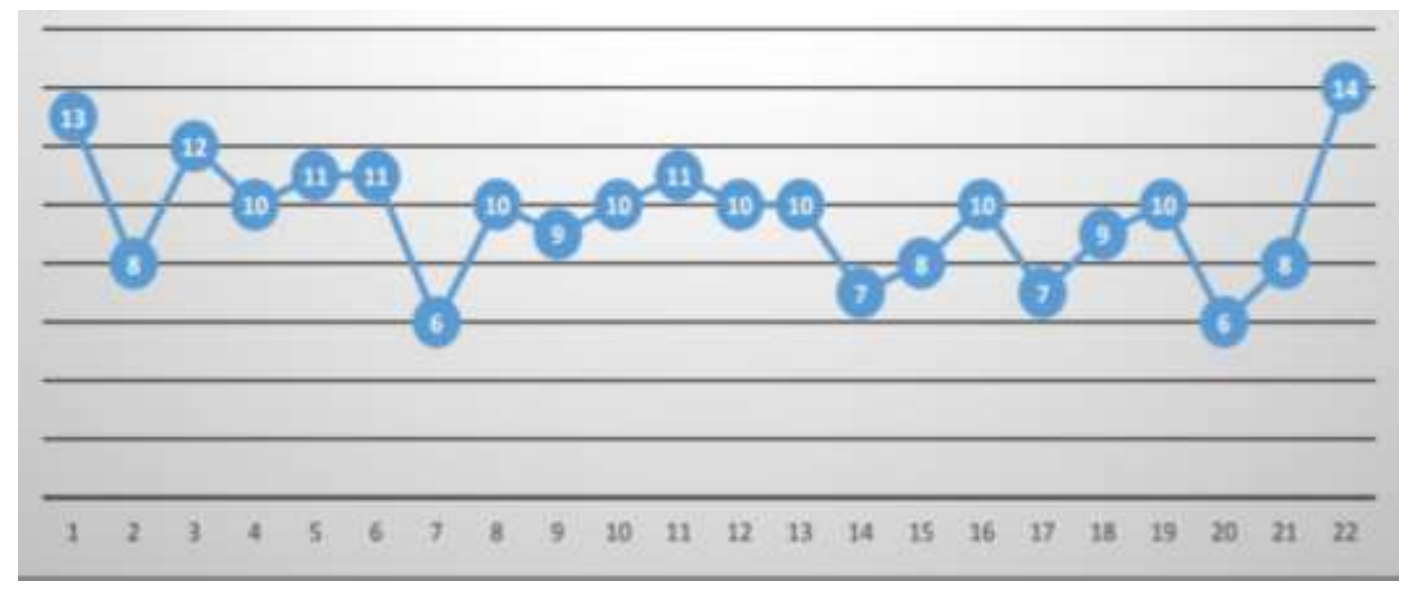

Gambar 3. Hasil Tes Kraeplin untuk Mengukur Konsentrasi Atlet Tenis

Program latihan pada aspek psikologis ini secara bertahap dapat dirasakan pengaruh yang positif terhadap perkembangan mental atlet selama menjalankan program latihan dimasa pandemi Covid 19. Program latihan harus tetap berjalan demi mempersiapkan atlet untuk dapat bersaing dan berprestasi di masa yang akan datang. Dengan program latihan yang simbang antara latihan fisik, teknik, taktik dan mental maka diharapkan prestasi olahraga tenis lapangan di Kabupaten Banyumas dapat semakin meningkat. 
Didik Rilastiyo Budi. Penulis lahir di Banyumas, 22 Juli 1988. Penulis merupakan dosen pada Prodi Pendidikan Jasmani, Fakultas Ilmu-ilmu Kesehatan, Universitas Jenderal Soedirman. Bidang keimuan yang digeluti oleh penulis adalah pendidikan olahraga dan ilmu keolahragaan. Penulis mengajar mata kuliah Tenis Lapangan, Senam, Organisasi Pertandingan, Perencanaan Pembelaran dan Penulisan Karya Tulis Ilmiah. Penulis menyelesaikan gelar sarjana Pendidikan Jasmani, Kesehatan, dan Rekreasi di Universitas Pendidikan Indonesia tahun 2011, sedangkan gelar magister Pendidikan Olahraga diselesaikan di Universitas Pendidikan Indonesia tahun 2015. Penulis berperan aktif pada organisasi Tenis Lapangan baik di lingkungan kampus maupun tingkat daerah, serta aktif mengelola Jurnal Ilmiah di Jurusan Pendidikan Jasmani yaitu Physical Activity Journl (PAJU).

\section{DAFTAR PUSTAKA}

Budi, D. R., Agustan, B., Listiandi, A. D., Hidayat, R., Festiawan, R., Hanief, Y. N., Qohhar, W., Setiawan, A., \& Nur, L. (2020). Tennis injury: Analysis and preventions actions among national junior tennis athlete. International Journal of Psychosocial Rehabilitation. https://doi.org/10.37200/IJPR/V24I8/PR280805

Budi, D. R., Syafei, M., Kusuma, M. N. H., Suhartoyo, T., Hidayat, R., \& Listiandi, A. D. (2020). The significance of exercise method on forehand and backhand groundstroke skills improvement in tennis. Jurnal SPORTIF: Jurnal Penelitian Pembelajaran. https://doi.org/10.29407/js_unpgri.v6i1.13920

Effendi, H. (2016). Peranan psikologi olahraga dalam meningkatkan prestasi atlet. Nusantara Jurnal Ilmu Pengetahuan Sosial. https://doi.org/http://jurnal.umtapsel.ac.id/index.php/nusantara/article/view/90/90

Kamnuron, A., Hidayat, Y., \& Nuryadi, N. (2020). Perbedaan Kepercayaan Diri Pada Siswa yang Mengikuti Ekstrakurikuler Olahraga. Physical Activity Journal. https://doi.org/10.20884/1.paju.2020.1.2.2394

Kusuma, M. N. H., Syafei, M., \& Budi, D. R. (2019). Biomekanika Olahraga. Unsoed Press.

Kusuma, M. N. H., Syafei, M., \& Rilastiyo, D. (2019). The Effect of Nutritional Status, Level of Physical Activity and Hemoglobins on Physical Endurance. JUARA : Jurnal Olahraga. https://doi.org/10.33222/juara.v4i2.607

Sahan A, Erman KA, \& Ertekin E. (2018). The effect of a variable practice method on tennis groundstroke learning of adult beginners. (TUR) ITF Coaching and Sport Science Review, 74(26). 
Sayfei, M., Budi, D. R., Himawan Kusuma, M. N., \& Listiandi, A. D. (2020). Identifikasi Keberbakatan Menggunakan Metode Australian Sport Search Terhadap Kesesuaian Cabang Olahraga Pada Anak Sekolah Dasar. Physical Activity Journal. https://doi.org/10.20884/1.paju.2020.1.2.2285

Syafei, M., Budi, D. R., Kusuma, M. N. H., \& Hidayat, R. (2019). Buku Ajar Tenis Lapangan (1st $\quad$ ed.). $\quad$ Unsoed https://isbn.perpusnas.go.id/Account/SearchBuku?searchCat=Judul\&searc $\mathrm{hTxt}=\mathrm{Buku}+\mathrm{Ajar}+$ Tenis+Lapangan

Syafei, Muhamad, Budi, D. R., Listiandi, A. D., Festiawan, R., Kusnandar, K., Nurcahyo, P. J., Stephani, M. R., \& Qohhar, W. (2020). Functional Movement Screening: An Early Detection of The Student Injury Risk in Sport Class. Jurnal Pendidikan Jasmani Dan Olahraga. https://doi.org/10.17509/jpjo.v5i2.25466 